\title{
Endoparasites in wild birds in the Brazilian Amazon
}

\section{Endoparasitos em aves silvestres na Amazônia brasileira}

\author{
Leandro Siqueira de Souza ${ }^{1 *}$ (D), Ângela Maria Fortes de Andrade ${ }^{2}$ (iD) Edson Guilherme ${ }^{3}$ (1) \& \\ Francisco Glauco de Araújo Santos ${ }^{4}$ (i) \\ 'Biologist. Laboratório de Apoio a Vida Silvestre, Universidade Federal do Acre - UFAC, Rio Branco, AC, Brasil \\ Veterinary, MSc, PhD student. Sanidade e Produção Animal Sustentável na Amazônia Ocidental, Universidade Federal do \\ Acre (UFAC), Rio Branco AC, Brasil \\ ${ }^{3}$ Biologist, Dr. Laboratório de Ornitologia, Universidade Federal do Acre - UFAC, Rio Branco AC, Brasil \\ ${ }^{4}$ Veterinary, Dr. Laboratório de Apoio a Vida Silvestre, Universidade Federal do Acre - UFAC, Rio Branco AC, Brasil
}

\begin{abstract}
Wild birds host a wide variety of endoparasites. These endoparasites are important because they can cause serious infections in birds. The present study aimed to conduct a copro-parasitological survey in wild birds captured in the Cazumbá-Iracema Extractive Reserve (Resex) located in the county of Sena Madureira, State of Acre, in northern Brazil. In order to capture these birds, ornithological mist nets were placed in different ecosystems of the Resex. Captured birds were identified and held in cloth sacks for 30 min. Fecal samples, from each bird, were collected if available. Direct examination and spontaneous sedimentation were used to analyze these samples. The prevalence rate of endoparasite infections in the fecal samples examined was 70.58\% (72/102). Oocysts and cysts of protozoa were detected in 69.44\% (50/72) of the samples, whereas helminth eggs were seen in $75.00 \%$ (54/72) of these specimens. To date, the southwest of the Amazon rainforest, northern Brazil, is a poorly explored area that warrants further research on the parasitic fauna of wildlife.
\end{abstract}

Keywords: wild birds, Cazumbá-Iracema Extractive Reserve (Resex), ecosystem health, parasitological diagnosis, enteroparasites, sanitary management.

\section{Resumo}

As aves silvestres são hospedeiras de uma grande variedade de endoparasitos. Esses endoparasitos são importantes, pois podem causar infecções graves às aves. O presente estudo teve como objetivo realizar um estudo copro-parasitológico em aves silvestres capturadas na Reserva Extrativista Cazumbá-Iracema (Resex) localizada no município de Sena Madureira, no estado do Acre, norte do Brasil. Para capturar essas aves, redes ornitológicas foram dispostas em diferentes ecossistemas da Resex. As aves capturadas foram identificadas e mantidas em sacos de pano por 30 minutos. Amostras fecais de cada ave foram coletadas, se disponíveis. O exame direto e a sedimentação espontânea foram os métodos utilizados para analisar as amostras. As amostras positivas para coccideos foram submetidas a técnica de Ziehl-Neelsen modificada. A taxa de prevalência de infecções endoparasitárias nas amostras fecais examinadas foi de $70,58 \%$ (72/102). Oocistos e cistos de protozoários foram detectados em 69,44\% (50/72) das amostras, enquanto ovos de helmintos foram observados em 75,00\% (54/72) desses espécimes. Até o momento, esta éuma área pouco explorada que merece mais pesquisas sobre a fauna parasitária de animais silvestres no sudoeste da floresta amazônica.

Palavras-chave: aves silvestres, Reserva Extrativista de Cazumbá-Iracema (Resex), saúde do ecossistema, diagnóstico parasitológico, enteroparasitos, manejo sanitário.

\section{Introduction}

Coproparasitological surveys, which focused on human infections until the 1970s, gave space and attention to analyses of the frequency of parasitism in indigenous and exotic animals (Ferreira et al., 1994; Bunbury et al., 2008). Birds have now gained prominence in this research due to their diversity in different geographical areas and also because they are hosts to a great diversity of parasites that pose a threat to animal and human health (Costa et al., 2010).

Of the health problems that affect wild birds, parasitic infections stand out as one of the most significant groups of avian disease because they can cause serious infections that can ultimately cause the death of infected hosts (Reed et al., 2003). Endoparasitic infections are a major public
How to cite: Souza, L. S., Andrade, A. M. F., Guilherme, E. \& Santos, F. G. A. (2019). Endoparasites in wild birds in the Brazilian Amazon. Brazilian Journal of Veterinary Medicine, 41, e105219. doi: 10.29374/2527-2179.bjvm105219.

Financial support: Conselho Nacional de Desenvolvimento Científico e Tecnológico (CNPq).

Conflict of interests: No conflict of interests declared concerning the publication of this article.

Received: May 05, 2019.

Accepted: September 12, 2019.

The study was carried out at Laboratório de Apoio a Vida Silvestre, Universidade Federal do Acre - UFAC, Rio Branco, AC, Brasil.

\section{*Correspondence}

Leandro Siqueira de Souza

Laboratório de Apoio a Vida Silvestre, Universidade Federal do Acre - UFAC CEP 69915-900 - Rio Branco (AC), Brasil E-mail: leandrosiqueirasouza@gmail.com. 
health concern as they can aggravate a number of other health problems. This is particularly true in developing countries where parasitic, neglected zoonotic diseases affect a large number of individuals (Costa et al., 2010).

Internal parasites can affect the health of the parasitized avian hosts in such a way that, depending on the severity of the infestation, they may lead to a rapid decline or even extinction of an avian population (Thompson, 2013).

There are a few published studies on the occurrence of internal parasites in wild birds from the Amazon biome. Magalhães-Matos et al. (2016) carried out a survey to determine parasite prevalence in wild birds raised in captivity in the state of Pará, northern Brazil. The authors examined fecal samples using light microscopy, and they detected helminth eggs and oocysts in these specimens. In the state of Acre, also in northern Brazil, a study conducted at the Federal University of Acre campus, on the occurrence of internal parasites in wild birds showed that these avian hosts are parasitized by protozoa and gastrointestinal helminths (Brito et al., 2017).

The State of Acre hosts more than 700 species of birds and many of them are endemic to the southwestern Amazon region (Guilherme, 2012, 2016). Despite this impressive array of birds, little is known about the endoparasites that infest avian hosts in Acre.

The lack of information on parasitic infections affecting wildlife in the Amazon, particularly for wild birds, warrants further research. Therefore, it is an opportune time to study the gastrointestinal parasites affecting free-living wild birds in the central-eastern region of the State of Acre, Brazil.

The present study aimed to conduct a coproparasitological survey in wild birds captured in the Cazumbá-Iracema Extractive Reserve (Resex) located in the county of Sena Madureira, State of Acre, north of Brazil.

\section{Materials and methods}

The present study was carried out in the Cazumbá-Iracema Extractive Reserve (Resex), which is a Federal conservation unit located in the State of Acre, southwestern Amazonia, Purus River basin, in the county of Sena Madureira (9 $\left.9^{\circ} 08^{\prime} 46.7^{\prime \prime S} 69^{\circ} \mathrm{O1} 1^{\prime} 17.7^{\prime \prime} \mathrm{W}\right)$, northern Brazil.

Birds were captured from September 2016 to May 2018. Seven ornithological mist nets were placed in four different ecosystems for 2 months: (a) pasture, (b) anthropic clearing, (c) secondary forest (in regeneration), and (d) primary forest. Nets were kept open during the mornings (from $5 \mathrm{AM}$ to $12 \mathrm{PM}$ ) and afternoons (from $2 \mathrm{PM}$ to $5 \mathrm{PM}$ ). The captured birds were identified and kept in cloth bags with absorbent paper inside. The birds were rested for $30 \mathrm{~min}$ until they defecated and the feces were collected, with only one fecal sample being collected from each individual. Fecal samples were conditioned in $50 \mathrm{~mL}$ flasks containing merthiolate-iodineformaldehyde (MIF) solution. The feces were then examined for parasites using light microscopy (Olympus CX40) at the Research Support Unit and Laboratory Services for Wildlife of the Federal University of Acre (UFAC) in Rio Branco, Acre, Brazil.

The diagnosis of parasitic infection in each bird was made using laboratory methods to find oocysts, eggs, and larvae: (1) direct smear examination of fresh fecal material using light microscopy stained with Lugol solution, and (2) spontaneous sedimentation (De Carli, 2001), using $10 x$ and $40 x$ lenses for visualization. The positive samples for coccidia were submitted to modified Ziehl-Neelsen technique (Lenette et al., 1985). These parasites were identified according to Foreyt (2005), and Zajac \& Conboy (2006).

Bird capture and sample collection were authorized by the Biodiversity Information and Authorization System-SISBIO N. 67436297 and by the Animal Research Ethics Committee-CEUAN. 2107.009788/2016-01.

Captured birds were identified by one of the authors (EG) who is the researcher in charge of the Ornithology Laboratory at UFAC. The classification of birds and the species nomenclature that were used in the present study were taken from Piacentini et al. (2015).

\section{Results}

Fecal samples were collected from 102 individuals and screened for the presence of parasites (Table 1). Of these, 18 individuals of seven species were non-Passeriformes (Pelecaniformes, Apodiformes, Coraciiformes and Galbuliformes) and 91 individuals of 45 species belonged to 
the Passeriformes order (Table 1). Of the 18 non-Passeriformes individuals with fecal samples, 83.33\% ( $n=15)$ presented infection by endoparasites, and 62.63\% $(n=57)$ of the fecal samples from 91 individual Passeriformes were positive for endoparasites.

Of the 102 fecal samples analyzed, endoparasites were detected in $70.58 \%$. Oocysts were detected in $69.44 \%$ (50/72) of the fecal samples examined, whereas helminth eggs were observed in $75.00 \%$ (54/72) of the fecal samples analyzed. Fourteen types of internal parasites were found in the avian fecal samples tested: $35.71 \%$ were protozod; $50 \%$ were nematode, $14.28 \%$ were cestode, and $7.14 \%$ ) were trematode.

Table 1. Results of the parasitological examination of fecal samples from wild birds captured in the Cazumbá-Iracema Extractive Reserve (Resex), Acre, Brazil. AC - total of samples collected and P - total of positive samples.

\begin{tabular}{|c|c|c|c|}
\hline Taxon & AC & $\mathbf{P}$ & Endoparasites \\
\hline \multicolumn{4}{|l|}{ Pelecaniformes } \\
\hline Ardea alba & 1 & 1 & Eimeria sp., Capillaria sp., Echinostomatidae \\
\hline \multicolumn{4}{|l|}{ Apodiformes } \\
\hline Glaucis hirsutus & 8 & 6 & Echinostomatidae, Eimeria sp., Entamoeba sp., Strongyloides sp. Ascaroidea \\
\hline Phaethornis hispidus & 1 & 1 & Oxyuroidea \\
\hline Amazilia lactea & 1 & 1 & Eimeria sp., Entamoeba sp., Syngamidae, Isospora sp. \\
\hline \multicolumn{4}{|l|}{ Coraciiformes } \\
\hline Momotus momota & 3 & 2 & Entamoeba sp., Isospora sp. Ascaroidea \\
\hline \multicolumn{4}{|l|}{ Galbuliformes } \\
\hline Galbula cyanescens & 2 & 2 & Capillaria sp., Ascaroidea, Entamoeba sp., Strongyloidea \\
\hline Monasa nigrifrons & 2 & 2 & Eimeria sp., Ascaroidea \\
\hline Sub total & 18 & 15 & \\
\hline \multicolumn{4}{|l|}{ Passeriformes } \\
\hline Epinecrophylla leucophthalma & 1 & 1 & Eimeria sp. \\
\hline Myrmotherula oreni & 1 & 0 & - \\
\hline Myrmotherula sp. & 1 & 1 & Eimeria sp. \\
\hline Isleria hauxwelli & 2 & 1 & Ascaroidea, Eimeria sp., Davaineidae \\
\hline Thamnomanes ardesiacus & 3 & 2 & Entamoeba sp., Oxyuroidea, Ascaroidea \\
\hline Thamnomanes schistogynus & 3 & 2 & Davaineidae \\
\hline Thamnophilus doliatus & 2 & 2 & Entamoeba sp., Ascaroidea, Oxyuroidea \\
\hline Taraba major & 3 & 2 & Ascaroidea, Entamoeba sp. \\
\hline Hylophylax naevius & 1 & 0 & - \\
\hline Hypocnemis peruviana & 2 & 1 & Heterakidae \\
\hline Myrmoborus leucophrys & 3 & 3 & Eimeria sp., Entamoeba sp., Ascaroidea \\
\hline Willisornis poecilinotus & 3 & 2 & Dilepididae, Eimeria sp., Strongyloides sp. \\
\hline Phlegopsis nigromaculata & 4 & 3 & Eimeria sp., Davaineidae, Ascaroidea \\
\hline Pheugopedius genibarbis & 3 & 2 & Eimeria sp., Ascaroidea, Oxyuroidea \\
\hline Sclerurus caudacutus & 1 & 0 & - \\
\hline Glyphorhynchus spirurus & 3 & 3 & Heterakidae, Entamoeba sp., Echinostomatidae \\
\hline Xiphorhynchus guttatoides & 3 & 2 & Strongyloides sp., Oxyuroidea, Iodamoeba sp., Strongyloidea \\
\hline Campylorhambus trochilirostris & 3 & 2 & Ascaroidea, Eimeria sp., Davaineidae, Isospora sp. \\
\hline Dendroplex picus & 2 & 2 & Ascaroidea \\
\hline Automolus rufipileatus & 1 & 1 & Eimeria sp., Strongyloides sp. \\
\hline Automolus ochrolaemus & 2 & 0 & - \\
\hline Neopelma sulphureiventer & 4 & 3 & Eimeria sp., Strongyloidea \\
\hline
\end{tabular}


Table 1. Continued...

\begin{tabular}{|c|c|c|c|}
\hline Taxon & AC & $\mathbf{P}$ & Endoparasites \\
\hline Pipra fasciicauda & 3 & 0 & - \\
\hline Ceratopipra rubrocapilla & 1 & 0 & - \\
\hline Machaeropterus pyrocephalus & 2 & 1 & Ascaroidea, Entamoeba sp., Oxyuroidea, Eimeria sp. \\
\hline Terenotriccus erythrurus & 1 & 0 & - \\
\hline Myiobius atricaudus & 3 & 1 & Entamoebasp. \\
\hline Mionectes oleagineus & 1 & 0 & - \\
\hline Corythopis torquatus & 1 & 1 & Ascaroidea, Strongyloides sp., Entamoeba sp., Capillaria sp. \\
\hline Rhynchocyclus olivaceus & 3 & 2 & Ascaroidea, Heterakidae, Entamoeba sp. \\
\hline Tolmomyias flaviventris & 1 & 1 & Entamoeba sp., Ascaroidea \\
\hline Ramphotrigon megacephalum & 1 & 1 & Entamoeba sp. \\
\hline Myiarchus ferox & 2 & 0 & - \\
\hline Megarynchus pitangua & 1 & 1 & Echinostomatidae, Davaineidae \\
\hline Tyrannus melancholicus & 2 & 2 & Strongyloides sp., Ascaroidea \\
\hline Troglodytes musculus & 2 & 2 & Isospora sp., Eimeria sp. \\
\hline Tangara episcopus & 1 & 1 & Strongyloides sp., Oxyuroidea, Entamoeba sp. \\
\hline Tangara palmarum & 2 & 2 & Entamoeba sp., Isospora sp., Oxyuroidea, Ascaroidea \\
\hline Volatiniajacarina & 1 & 1 & Isospora sp., Eimeria sp., Entamoeba sp. \\
\hline Sporophila angolensis & 6 & 3 & Entamoeba sp. \\
\hline Sporophila castaneiventres & 1 & 1 & Isospora sp., Ascaroidea \\
\hline Saltator maximus & 1 & 0 & - \\
\hline Brotogeris cyanoptera & 2 & 0 & - \\
\hline Furnarius leucopus & 1 & 1 & Eimeria sp., Capillaria sp., Strongyloides sp., \\
\hline Turdus ignobilis & 1 & 1 & Davaineidae \\
\hline Sub total & 91 & 57 & \\
\hline Total & 109 & 72 & \\
\hline
\end{tabular}

Table 2. Frequency of endoparasites in the 44 birds species captured in the Cazumbá-Iracema Extractive Reserve (Resex), Acre, Brazil.

\begin{tabular}{lc}
\hline Parasites & Frequency (\%) \\
\hline PROTOZOA & \\
Entamoeba sp. & 35.84 \\
Iodamoeba sp. & 1.88 \\
Eimeria sp. & 33.96 \\
Isospora sp. & 13.20 \\
NEMATODES & \\
Capillaria sp. & 7.54 \\
Ascaroidea & 37.73 \\
Heterakidae & 4.16 \\
Strongyloides sp. & 16.98 \\
Strongyloidea & 5.66 \\
Oxyuroidea & 15.09 \\
Syngamidae & 1.88 \\
TREMATODES & \\
Echinostomatidae & 7.54 \\
CESTODES & \\
Dilepididae & 1.88 \\
Davaineidae & 13.20
\end{tabular}


Three parasites were frequently detected among the 53 species of birds with samples analyzed: Ascaroidea (37.73\%, n = 20), Entamoeba sp. (35.84\%, n = 19), and Eimeria sp. (33.96\%, n = 18). The least frequently detected endoparasites were Dilepididae $(1.38 \%, n=1)$, Syngamidae $(1.88 \%$, $\mathrm{n}=1)$ and Iodamoeba sp. $(1.88 \%, \mathrm{n}=1)$ (Table 2$)$.

\section{Discussion}

There are few published studies on wild bird endoparasites that are similar to our study in which avian hosts were studied in their natural habitat (Marques et al., 2007; Costa et al., 2010; Luz et al., 2014; Brito et al., 2017).

Theinfestation rate of wild bird species captured in the Cazumbá-Iracema Resex was high: almost all of the sampled species showed some type of endoparasite. The results of the parasitological examination of the avian fecal samples, in the present study, using light microscopy show that the percentage of parasitized birds in our survey was higher than in a previous study conducted by Magalhães-Matos et al. (2016) in the State of Pará, northern Brazil, in which only 43.18\% of the birds sampled were infected with internal parasites. The discrepancy between our findings and the findings previously published by other researchers may have been due to the fact that the wild birds analyzed in the State of Pará by Magalhães-Matos et al. (2016) were in captivity. However, when the results of our study were compared with the results from a previous study carried out by Brito et al. (2017), in which fecal samples from free-living wild birds at the university campus and Zoobotanical Park (PZ) of UFAC were examined, the results of each of these surveys (70.5\% versus $70.4 \%$, respectively) were highly similar to those in this study.

Eggs of Ascaroidea, cysts of Entamoeba sp. and oocysts of Eimeria sp. were generalist parasites, and they occurred in 20,19, and 18 of the bird species studied, respectively. Cysts of Iodamoeba sp., eggs of Dilepididae and Syngamidae were more specialist parasites, and they were seen in the bird species Xiphorhynchus guttatoides, Willisornis poecilinotus, and Amazilia lactea, respectively. Among the protozoa that can induce disease in avian hosts, the coccidium Eimeria sp., which causes coccidiosis in birds, is cosmopolitan (Hubálek, 2004). This pathogen is considered the most important endoparasite in poultry farming. These coccidia cause diarrhea, apathy, decrease in egg production, weight loss, and ultimately death, especially in young birds (Júnior \& Macari, 2000).

Marques et al. (2007) assessed the prevalence of gastrointestinal parasites in pigeons from urban areas in the city of Lages, State of Santa Catarina, southern Brazil, and they found that 86.05\% (37/43) of the birds were parasitized by protozoa. Oocysts of Eimeria sp. were detected in all fecal samples examined under the light microscope.

Marietto-Gonçalves et al. (2009) carried out a study on parasitic infections in 11 orders of wild birds (Ciconiformes, Columbiformes, Coraciiformes, Craciformes, Gruiformes, Passeriformes, Piciformes, Psittaciformes, Strigiformes, and Struthioniformes and Galliformes) of which, five (Ciconiiformes, Passeriformes, Galliformes, Piciformes and Psittaciformes) were parasitized. The parasites found by the authors were Ascaridia sp., Balantidium sp., Blastocystis sp., Capillaria sp., coccídios, Entamoeba sp., and Heterakis sp.

Eggs of Capillaria sp. were found in three different bird species (Ardea alba - great egret, Galbula cyanescens - bluish-fronted jacamar, and Corythopis torquatus - ringed antpipit). Capillaria is one of the most pathogenic helminths for birds, and it can cause inappetence, emaciation, and diarrhea due to inflammation of the gastrointestinal tract (Júnior \& Macari, 2000).

The presence of eggs of Ascaroidea, Heterakidae, and Davaineidae corroborates the results found by Giovannoni \& Kubiak (2001), who described the parasitic fauna of helminths in domestic animals necropsied in different parts of the gastrointestinal tract, and by Brito et al. (2017) when analyzing the endoparasites of free-living wild birds in the Campus and PZ of UFAC. D'Ávila et al. (2017) in a study on helminths of Columba livia in the city of Juiz de Fora, State of Minas Gerais, southeastern Brazil, reported the presence of Davaineidae of the genus Raillietina sp.

Eggs of Strongyloides sp., cysts of Entamoeba sp. and oocysts of Isospora sp. were found in this study and also described by Snak et al. (2014) in 228 fecal samples from 37 captive bird species, in 22 enclosures of the Danilo Galafassi Municipal Park, in Cascavel - PR, finding parasites of the genera Strongyloides, Eimeria, Capillaria, Deletrocephalus, and Isospora. Magalhães-Matos et al. (2016) found a high prevalence of Isospora oocysts in wild birds bred in captivity in Pará, and in 163 samples analyzed by them, 71 (43.56\%) were contaminated with these endoparasites. 
Freitas et al. (2002) analyzed wild birds kept in captivity in the State of Pernambuco, northeastern Brazil and reported a high incidence of parasites, and of the 685 birds studied, 320 were parasitized with Capillaria sp., Strongyloides sp., Ascaridia sp., Heterakis sp., Spiruroide, Cestodea, Trematoda, Coccidia, Entamoeba coli, E. histolytica, and Balantidium coli.

Costa et al. (2010) only detected cysts of Iodamoeba sp. in Xiphorhynchus guttatoides, in a study on gastrointestinal parasites in wild birds in the municipality of Seropédica, State of Rio de Janeiro, southeastern Brazil, where they reported the presence of trichomonadidae, Chilomastix, coccidia, Entamoeba coli, Iodamoeba butschlii, and helminth eggs. The presence of cysts of Entamoeba sp. and Iodamoeba sp. in the local avifauna is worrying, because according to Costa et al. (2010), these protozoan parasites may be opportunistic pathogens in bird infections, and they are zoonotic.

Eggs of Dilepididae, Echinostomatidae, Oxyuroidea, and Strongyloidea in this study corroborates the results found by Brasil \& Amato (1992), in a faunal analysis of the helminths of sparrows (Passer domesticus) captured in Campo Grande, State of Rio de Janeiro, southeastern Brazil. Brito et al. (2017) also found these parasites in the wild birds captured in the Campus and Zoobotanical Park of the Federal University of Acre.

The eggs of the nematode Syngamidae were found in the feces of Amazilia lactea, and this finding corroborates previous research published by Marques \& Amato (2010). These authors carried out a survey on parasites affecting Turdus rufiventris (rufous-bellied thrush) in the metropolitan region of the city of Porto Alegre, State of Rio Grande do Sul, southern Brazil, where Syngamus trachea was seen infesting mainly immature birds.

However, infection by the eggs of cestode Davaineidae is a result that is similar to those published by D'Ávila et al. (2017). These authors studied helminths of Columba livia (rock dove) in the county of Juiz de Fora, State of Minas Gerais, southeastern Brazil, and they reported the presence of worms from the Davaneidae family. To our knowledge, eggs of Syngamidae have not been reported in wild birds in the State of Acre, being the only internal parasites found in our study that were not found in a previous study carried out by Brito et al. (2017).

Some of the endoparasites reported in the present study can pose a significant risk to wildlife health. They can be opportunistic or the primary cause of a disease (Daszak et al., 2000). These birds inhabit different geographical areas in the Resex and as a result, residents and domestic animals in this area may interact either directly or indirectly with infested wild birds, and they may end up acquiring some sort of parasitic infection from these birds.

The identification of the parasites found in this study was based on their morphometric characteristics, which hinders the differentiation between animal, human, and free-living parasites. For the proper identification of these parasites, it is necessary to use more sophisticated techniques that cannot be conducted in our laboratory such as culture, electron microscopy, and molecular biology. Even with our methodological limitations, we found parasites that may be pathogenic for both man and wild birds.

\section{Conclusion}

The wild birds of the Cazumbá-Iracema Extractive Reserve were parasitized by protozoa and helminths, with the order Passeriformes being the most studied and most parasitized. The main parasites were Ascaroidea, Entamoeba sp., and Eimeria sp.

\section{Acknowledgements}

The authors would like to thank Instituto Chico Mendes de Conservação da Biodiversidade (ICMBio), Sena Madureira office for support during the fieldwork; and to give special thanks to the Mr. José Acacio and Mrs. Francisca da Rocha, residents of the Cazumbá-Iracema Extractive Reserve for their support in catching the birds.

\section{References}

Brasil, M. R., \& Amato, S. B. (1992). Análise faunística dos helmintos de pardais (Passer Domesticus L., 1758) capturados em Campo Grande, Rio de Janeiro, RJ. Memorias do Instituto Oswaldo Cruz, 87(Suppl. 1), 43-48. http://dx.doi.org/10.1590/S0074-02761992000500009. 
Brito, A. S. A., Guilherme, E., Santos, F. G. A., Mesquita, R. P., \& Gomes, F. A. (2017). Endoparasites of wild birds from Campus area and Zoobotanical Park, at the Federal University of Acre, Rio Branco - Acre. Arquivos de Ciência Veterinária e Zoologia, 20(3), 117-122. http://dx.doi.org/10.25110/arqvet.v20i3.2017.6363.

Bunbury, N., Jones, C. G., Greenwood, A. G., \& Bell, D. J. (2008). Epidemiology and conservation implications of Trichomonas gallinae infection in the endangered Mauritian pink pigeon. Biological Conservation, 141(1), 153-161. http://dx.doi.org/10.1016/j.biocon.2007.09.008.

Costa, I. A., Coelho, C. D., Bueno, C., Ferreira, I., \& Freire, R. B. (2010). Ocorrência de parasitos gastrintestinais em aves silvestres no município de Seropédica, Rio de Janeiro, Brasil. Ciência Animal Brasileira, 11(4), 914-922. http://dx.doi.org/10.5216/cab.v11i4.7164.

D'Ávila, S., Bessa, E. C. A., \& Rodrigues, M. L. A. (2017). Composition and structure of the helminth community of Columba livia (Gmelin, 1798) (Aves, Columbidae) in the municipality of Juiz de Fora, Minas Gerais State, Brazil. Revista Brasileira de Zoociências, 18(2), 45-54. http://dx.doi.org/10.34019/2596-3325.2017.v18.24669.

Daszak, P., Cunningham, A. A., \& Hyatt, A. D. (2000). Emerging infectious diseases of wildlife threats to biodiversity and human health. Science, 287(5452), 443-449. http://dx.doi.org/10.1126/science.287.5452.443. PMid:10642539.

De Carli, G. A. (2001). Parasitologia Clínica: seleção de métodos e técnicas de laboratório para o diagnóstico das parasitoses humanas (2a ed.). São Paulo: Atheneu.

Ferreira, C. S., Ferreira, U. M., \& Nogueira, M. R. (1994). The prevalence of infection by intestinal parasites in urban slum in São Paulo, Brazil. The Journal of Tropical Medicine and Hygiene, 97(2), 121-127. PMid:8170003.

Foreyt, W. J. (2005). Parasitologia Veterinária: manual de referência (5a ed.). São Paulo: Roca.

Freitas, M. F. L., Oliveira, J. B., Cavalcanti, M. D. B., Leite, A. D., Magalhães, V. S., Oliveira, R. A., \& Evencio-Sobrinho A. (2002). Parasitos gastrointestinales de aves silvestres em cautiveiro em el Estado de Pernambuco, Brasil. Parasitología Latinoamericana, 57, 50-54.

Giovannoni, M., \& Kubiak, G. V. L. (2001). Fauna parasitológica paranaense. IV. Lista prévia da ocorrência de helmintos em animais domésticos. Arquivos de Biologia e Tecnologia, 2(0), 289-292. http://dx.doi.org/10.1590/ S1516-89132001000500011.

Guilherme, E. (2012). Birds of the Brazilian state of Acre: diversity, zoogeography, and conservation. Revista Brasileira de Ornitologia, 20, 393-442.

Guilherme, E. (2016). Aves do Acre (1a ed.). Rio Branco: Edufac.

Hubálek, Z. (2004). An annotated checklist of pathogenic microorganisms associated with migratory birds. Journal of Wildlife Diseases, 40(4), 639-659. http://dx.doi.org/10.7589/0090-3558-40.4.639. PMid:15650082.

Júnior, A. B., \& Macari, M. (2000). Doenças das aves (1a ed.). Campinas: Facta.

Lenette, E. H., Ballows, A., Hausler, W. J., \& Shadomy, H. J. (1985). Manual of clinical microbiology (4a ed.). Washington: American Society for Microbiology.

Luz, H. B., Landulfo, G. A., Santolin, I. D. A. C., Ribeiro, C. C. D. U., Pinheiro, M. C., \& Rodrigues, M. L. A. (2014). Endoparasites as environmental quality indicators in wild birds in Tinguá Biological Reserve, Rio de Janeiro, Brazil. Neotropical Helminthology, 8, 469-472.

Magalhães-Matos, P. C., Silva, M. B. V., Souza, P. G. S., Lima, D. H. S., Morais, R., \& Farias, D. M. (2016). Ocorrência de ovos e oocistos de parasitos gastrointestinais em aves Passeriformes mantidas em cativeiro no estado do Pará, Brasil. Ciência Rural, 46, 2177-2181.

Marietto-Gonçalves, A., Martins, T. F., Lima, E. T., Lopes, R. S., \& Andreatti, F. R. L. (2009). Prevalência de endoparasitas em amostras fecais de aves silvestres e exóticas examinadas no Laboratório de Ornitopatologia e no Laboratório de Enfermidades Parasitárias da FMVZ-UNESP/Botucatu-SP. Ciência Animal Brasileira, 10, 349-354.

Marques, C. C., \& Amato, B. S. (2010). Parasites as secret files of the trophic interactions of hosts: the case of the rufous bellied thrush. Revista Mexicana de Biodiversidad, 81, 801-811.

Marques, S. M. T., Quadros, R. M., Silva, C. J., \& Baldo, M. J. H. (2007). Parasites of Columbia Livia in urban área of lages, southern Brasil. Parasitología Latinoamericana, 62, 183-187.

Piacentini, V. Q., Aleixo, A., Agne, C. E., Mauricio, G. N., Pacheco, J. F., Bravo, G. A., Brito, G. R. R., Naka, L. N., Olmos, F., Posso, S., Silveira, L. F., Betini, G. S., Carrano, E., Franz, I., Lees, A. C., Lima, L. M., Pioli, D., Schunck, F., Amaral, F. R., Bencke, G. A., Cohn-Haft, M., Figueiredo, L. F. A., Straube, F. C., \& Cesari, E. (2015). Annotated checklist of the birds of Brazil by the Brazilian Ornithological Records Committee. Revista Brasileira de Ornitologia, 23, 91-298.

Reed, K. D., Meece, J. K., Henkel, J. S., \& Shukla, S. K. (2003). Birds, migration and emerging zoonoses: west nile virus, lyme disease, influenza A and enteropathogens. Clinical Medicine \& Research, 1(1), 5-12. http://dx.doi. org/10.3121/cmr.1.1.5. PMid:15931279.

Snak, A., Lenzi, P. F., Agostini, K. M., Delgado, L. E., Montanucci, C. R., \& Zabott, M. V. (2014). Análises Coproparasitológicas de Aves Silvestres Cativas. Ciência Animal Brasileira, 15(4), 502-507. http://dx.doi. org/10.1590/1089-6891v15i425797.

Thompson, R. C. A. (2013). Parasite zoonoses and wildlife: one health, spillover and human activity. International Journal for Parasitology, 43(12-13), 1079-1088. http://dx.doi.org/10.1016/j.ijpara.2013.06.007. PMid:23892130.

Zajac, A. M., \& Conboy, G. A. (2006). Veterinary Clinical Parasitology (7a ed.). Ames: Blackwell Publishing. 